\title{
Determinant of Adoption of Improved Varieties of Sorghum in Center-north and Boucle du Mouhoun in Burkina Faso
}

\author{
Silamana Barry ${ }^{*} \quad$ Mariam Myriam Dama Balima Sabine Nadembega \\ Institut de l'Environnement et de Recherches Agricoles (INERA). 04 BP 8645 Ouagadougou 04 Burkina Faso
}

\begin{abstract}
Sorghum is the first food cereal in Burkina Faso. Its average yield is of the order of $850 \mathrm{~kg} / \mathrm{ha}$ (Barro-Kondombo, 2010). Sorghum is listed as a priority plant in research and food security strategies. Local varieties remain dominant in the traditional farming system with a predominance of the botanical race Guinea (Barro-Kondombo et al., 2008). This study was conducted on 300 farmers in center-north and the Boucle du Mouhoun in Burkina Faso. The objective of this paper is to determine the socioeconomic factors influencing the adoption of improved varieties of sorghum in the aforementioned regions. An econometric model Probit was used. The results show that the area, training on the improved varieties, membership of a farmer organization, land area planted with sorghum, access to credit and the availability of improved varieties positively affect the probability of adopting improved varieties of sorghum. In contrast, the age of the producer negatively affects the probability of adoption of improved varieties of sorghum.
\end{abstract}

Keywords: adoption, improved varieties, sorghum, Probit, Burkina Faso, center-north, Boucle du Mouhoun. DOI: $10.7176 / \mathrm{JESD} / 10-4-08$

\section{Introduction}

More than two-third of population in Burkina Faso depends on agriculture as principal source of income (World Bank, 2016). Pearl millet and sorghum play an important role in achieving food security, as they constitute the basis of diet for a large majority of Burkinabé (DGPER, 2012). In Burkina Faso where sorghum is one of the main crop for achieving food security, yield decline which is preoccupant as well as archaic methods and climate changes render this portion of the population poor and fragile even though it contributes for $40 \%$ to the gross domestic product. Seed is the first input of agricultural production and its quality determines the success of production and commercialization chain of agricultural products. In Burkina Faso, within the context of climate change and demographic pressure, farmers are facing problems of unsuitable production cycles which have become too long and productivity decline of local varieties (vom Brocke et al. 2010). An increase of agricultural productivity in general will not be effective on condition that farmers get access and adopt technical innovations developed by the research. Among this innovations, improved varieties of sorghum occupy a place of choice. In fact, maize value chain remains one of the most targeted to ensure food security. In Burkina Faso, improved seeds constitute an important component in agricultural production. The Institut de l'Environnement et de Recherches Agricoles (INERA) has released several improved sorghum varieties. However, the adoption rate of improved varieties all crops included is low, about 11.2\% (DGPER, 2012). Several raisons explain this low adoption rate. Therefore, it is necessary to identify the factors that influence the adoption of improved varieties in order to formulate recommendations. Studies showed that at least $40 \%$ of yield increase is registered with improved varieties. But why the adoption rate of such varieties never goes beyond $10 \%$. This is the research question addressed by this paper that aimed at determining the factors influencing the adoption of improved varieties of sorghum in the study regions. Sorghum is of particular importance in Burkina Faso in terms of its production, consumption as well as its commercialization. This crop has socioeconomic implications. Exportations of sorghum have evolved between 2012 and 2017 from 1.1 billion to 3.8 billion CFAF respectively. Sorghum constitutes the basic food for the majority of people in Burkina Faso. The number of sorghum producers is estimated at more than 1.2 million (DGPER, 2012).

\section{Theoretical context of innovation, diffusion}

The economic theory underlying the econometric model on the adoption is the maximization of utility. The theory of the maximization of utility is often used to explain producer's response to a new technology. The analysis of adoption of agricultural technologies is based on the principle of rationality of the economic agents and particularly the hypothesis of maximization of utility. A rational reaction of a producer leads him to adopt a technological innovation that gives him more utility. For Rogers (1995), five main factors determine the adoption or the diffusion of a new technology. These factors are: relative advantage, complexity, compatibility, testability and observation. He estimates that a combination of these factors has more positive impact on the adoption of technologies. A farmer who decides to adopt a new variety of sorghum does it based on its own criteria related to the technological and environmental characteristics. The literature review of adoption of innovations allowed to distinguish three types of models frequently used to analyze the decision of adopting new agricultural technology: models of linear probability, Logit and Probit. Logit and Probit models are often used in most adoption studies. In this study we 
used an econometric modulation with Probit model as analysis tool because it has been judged as appropriate for the certification of relations between a probability of adoption and its determinants (Ntsama et Kamgnia, 2012; Barry, 2016). In fact, it is assumed that the adoption of an improved variety of sorghum by randomly selected farmers' follows a normal distribution.

\section{Methodology}

The methodology comprises the study area, data collection and analysis.

\subsection{Study area}

The study area concerns the regions of center-north and Boucle du Mouhoun in Burkina Faso. These regions was selected because they present two contrasting situations as regard to their climate. These two regions are located in two distinct agro-ecologies mainly differentiated by their rainfall. In fact, the region of center-north is located in the Sahelian eco-climate (less than $600 \mathrm{~mm}$ rainfall per year) and the region of Boucle du Mouhoun is in the Soudano-sahelian zone between the isohyets $600-900 \mathrm{~mm}$ rainfall per year. It is important to point out that these two regions had density of 13 and 21 inhabitant $/ \mathrm{km}^{2}$ in 2011 for center-north and Boucle du Mouhoun respectively (INSD, 2011). This is lower than the national average which is 38 inhabitants $/ \mathrm{km}^{2}$ (PAM, 2012) (fig 1: map of study area)

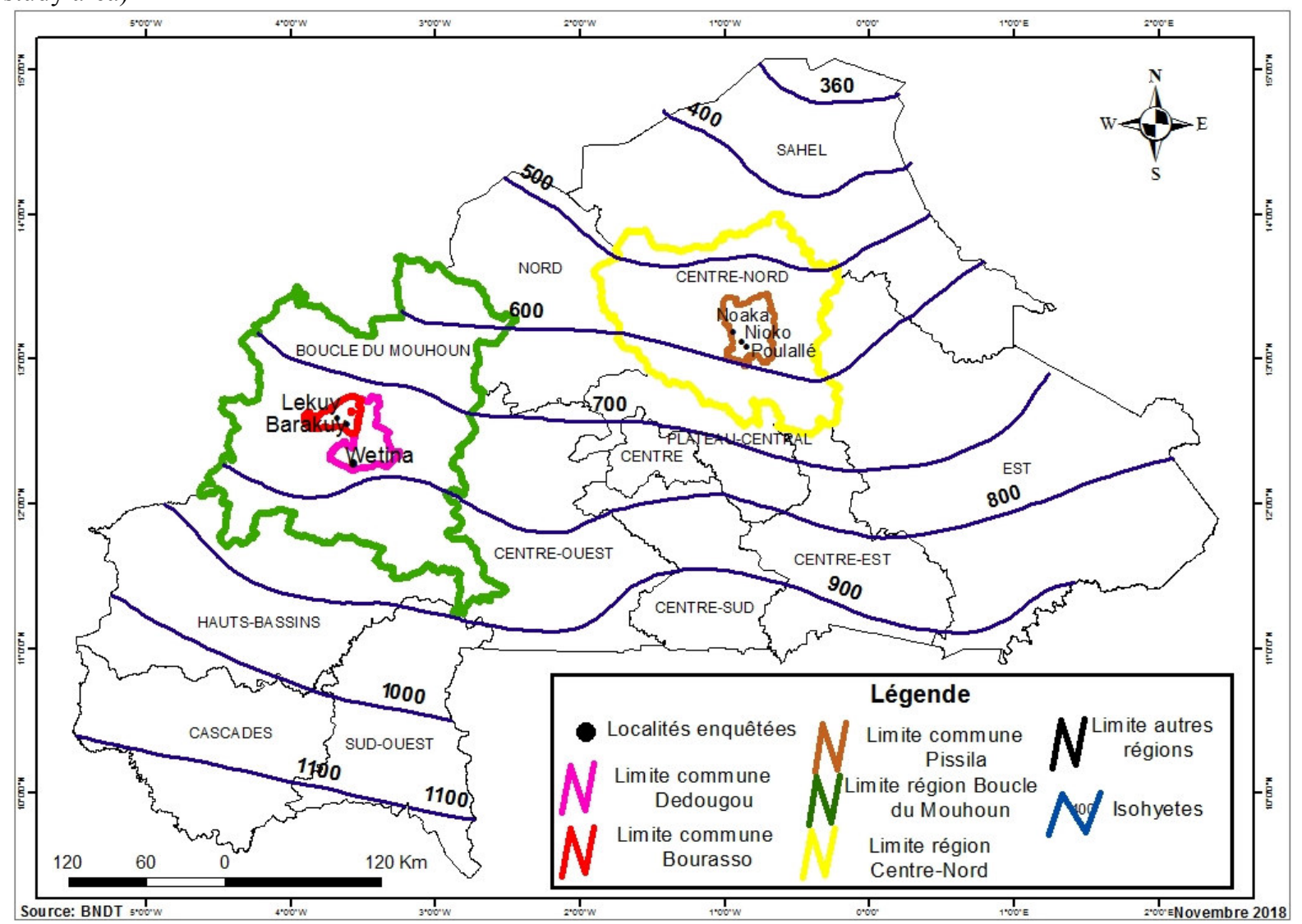

Figure 1: Map of the study area

\subsection{Econometric modeling}

The economic theory underlying the econometric model on the adoption is the maximization of utility. The theory of the maximization of utility is often used to explain a producer's response to a new technology. The literature review of adoption of innovations allowed to distinguish three types of models frequently used to analyze the decision of adoption new agricultural technology: models of linear probability, Logit and Probit. Logit and Probit models are often used in most adoption studies. In this study we used an econometric modulation with Probit model as analysis tool because it has been judged as appropriate for the certification of relations between a probability of adoption and its determinants (Ntsama et Kamgnia, 2012; Barry, 2016). In fact, it is assumed that the adoption of an improved variety of sorghum by randomly selected farmers' follows a normal distribution. Usually, to determine households' determinants of choice for adopting agricultural innovations, the economic theory uses adoption models. The goal of an adoption model is to explain a variability of an $\mathrm{Y}$ vector, representing the adoption of good practices, by $\mathrm{X}$ variable vector that represents explicative variables (such as the characteristics of the adopter, the 
innovation and the institutional environment).

Formally, the model can therefore be written: $Y=\beta X+\varepsilon$ where $\beta$ is a vector of coefficients to be determined, $\varepsilon$ an unknown vector which effect is imputable to variables that are not observed.

For a given producer i we have:

$$
Y_{i}\left\{\begin{array}{l}
=1 \text { if producer adoptes improve varieties of sorghum } \\
=0 \text { if not }
\end{array}\right.
$$

The decision of this producer $i$ to adopt seeds of an improved variety of sorghum is assumed to be based on the maximization of the utility of these improved varieties. Several models allow to perform regression of dependent variables for dichotomy variables $(1,0)$ the most expended being the Logit and Probit models. The difference between these two models lies in the specification of the distribution function.

The probability $\mathrm{P}$ such as: $\operatorname{Pi}=\operatorname{Prob}(Y i=1)=\operatorname{Prob}(U i 1>U i 0)=\operatorname{Prob}(X i 1+i 1>X i 0+i 0)=F$; when the agricultural innovation is adopted is therefore function of independent variables and error term. In this equation, $F$ represents the distribution function. If the distribution function is logistic, it refers to Logit model. If it is normal centered reduced, it is a Probit model (Bourbonnais, 2015). The Probit model fits to our dependent variable which is dichotomous. In addition, in the case of probit model, the dependent variable is qualitative. The distribution function will be therefore written:

$F\left(X_{i} \theta\right)=\int_{-\infty}^{x_{i} \theta} \exp \left(\frac{-t^{2} / 2}{\sqrt{2 \pi}}\right) d t$. In this expression, $X_{\mathrm{i}}$ is a characteristic vector of the adopter $\mathrm{i}$, the seeds of the improved sorghum and the institutional environment.

Table 1: list of variables of the model

\begin{tabular}{|c|c|c|}
\hline Variables & Description & Expected Sign \\
\hline \multicolumn{3}{|c|}{ Dependent variable } \\
\hline $\begin{array}{l}\text { Adoption of improved variety } \\
\text { of sorghum }\end{array}$ & $\begin{array}{l}\text { Binary variable is } 1 \text { if the producer adopts the improved } \\
\text { variety and } 0 \text { in the opposite }\end{array}$ & \\
\hline \multicolumn{3}{|c|}{ Independent variables } \\
\hline Agro-ecological zone & $\begin{array}{l}\text { Binary variable value is } 1 \text { if the producer is from the } \\
\text { agro-ecological region of center-north and } 0 \text { if not }\end{array}$ & Positive \\
\hline Age & It is a continuous variable. Age of the producer & Positive \\
\hline Sex & $\begin{array}{l}\text { It is a binary variable which value is } 1 \text { if the producer is } \\
\text { a man and } 0 \text { if a women }\end{array}$ & Positive \\
\hline $\begin{array}{l}\text { Membership of farmers' } \\
\text { organization }\end{array}$ & $\begin{array}{l}\text { It is a binary variable which value is } 1 \text { if the producer is } \\
\text { member of a farmer organization and } 0 \text { if not }\end{array}$ & Positive \\
\hline Land area of sorghum & Continuous variable. Land area in hectare & Negative \\
\hline Access to credit & $\begin{array}{l}\text { Binary variable value is } 1 \text { if the producer has access to } \\
\text { credit and } 0 \text { if not }\end{array}$ & Positive \\
\hline $\begin{array}{l}\text { Availability of improved } \\
\text { variety }\end{array}$ & $\begin{array}{l}\text { Binary variable value is } 1 \text { if improved varieties are } \\
\text { available and } 0 \text { it not }\end{array}$ & Positive \\
\hline $\begin{array}{l}\text { Training on improved } \\
\text { varieties }\end{array}$ & $\begin{array}{l}\text { Binary variable value is } 1 \text { if the producer benefited from } \\
\text { training on improved varieties and } 0 \text { if not }\end{array}$ & Positive \\
\hline Education level & $\begin{array}{l}\text { Binary variable value is } 1 \text { if the producer attended at least } \\
\text { to primary education level and } 0 \text { if not }\end{array}$ & Positive \\
\hline
\end{tabular}

\subsection{Data collection and analysis}

Three hundred farmers were interviewed by two investigators; 150 farmers being interviewed by each investigator per region. Surveyed districts are: Pissila in center-north and Dedougou and Bourasso in the Boucle du Mouhoum. Overall six villages were surveyed in the three districts. The villages from Pissila are: Nioko, Noaka and Poulallé. The villages in Bourasso are: Barakuy and Lekuy and the village from the district of Dedougou is Wétina. Fifty producers were interviewed per village making a total of 300 producers for the six villages. A reasoned choice of producers was made emphasizing on sorghum producers. Data were typed in SPSS software and analyzed with SPSS and STATA.

\section{Results and discussion}

Results of socio-economic characteristics and econometric modulation

\subsection{Socio-economic characteristics of the interviewed farmers}

Table 2 shows the socio-economic characteristics of the interviewed farmers. The results show that the variables agro-ecological zone, membership of farmers' organization, training, access to credit and availability of improved varieties statistical influence the adoption of improved varieties at $1 \%$ significance level. Education level influences the adoption of improved varieties at 5\% significance level. Average age of the interviewed farmers is 42.99 year while the average age of those who do not adopt is 41.11 and that of those who are adopting is 43.897 
year. The age influences the adoption of improved varieties of sorghum at $10 \%$ significance level (Table 2).

Table 2: socio-economic characteristics of farmers

\begin{tabular}{|l|l|l|l|l|l|l|}
\hline Variables & $\begin{array}{l}\text { Mean farmers } \\
\text { not } \\
\text { improved } \\
\text { varieties } \\
\text { sorghum }\end{array}$ & $\begin{array}{l}\text { Mean farmers } \\
\text { adopting } \\
\text { improved } \\
\text { varieties of } \\
\text { sorghum }\end{array}$ & Total & Differences & T & Probabilities \\
\hline $\begin{array}{l}\text { Agro- } \\
\text { ecological zone }\end{array}$ & 0.378 & 0.647 & 0.427673 & -0.269 & -4.798 & $0.0000^{* * *}$ \\
\hline Sex & 0.646 & 0.713 & 0.7798742 & -0.066 & - & 0.2189 \\
\hline $\begin{array}{l}\text { Age } \\
\text { Level of } \\
\text { education }\end{array}$ & 0.542 & 43.897 & 42.99371 & -2.781 & - & $0.0546^{*}$ \\
\hline $\begin{array}{l}\text { Membership of } \\
\text { farmers } \\
\text { organization }\end{array}$ & 0.414 & 0.669 & 0.6226415 & -0.126 & -2.236 & $0.0261^{* *}$ \\
\hline $\begin{array}{l}\text { Land area of } \\
\text { sorghum }\end{array}$ & 1.9268 & 0.705 & 0.5849057 & -0.291 & -5.255 & $0.000^{* * *}$ \\
\hline $\begin{array}{l}\text { Training on } \\
\text { improved } \\
\text { varieties }\end{array}$ & 0.03049 & 2.222 & 2.272327 & -0.297 & -0.971 & 0.3329 \\
\hline Access to credit & 0.115 & 0.3161 & 0.245283 & -0.285 & -7.26 & $0.0000^{* * *}$ \\
\hline $\begin{array}{l}\text { Availability of } \\
\text { improved } \\
\text { varieties }\end{array}$ & 0.529 & 0.257 & 0.2075472 & -0.141 & -3.219 & $0.0014^{* * *}$ \\
\hline$* *$ significant at $1 \%, * *$ significant at $5 \% *$ significant at $10 \%$ & -0.293 & -4.22 & $0.0000^{* * *}$ \\
\hline
\end{tabular}

\subsection{Results of the econometric modeling}

The results of the econometric modeling show that some variables positively influence adoption of improved varieties while some negatively influence it. Some variables are not significant meaning that they do not influence the adoption of improved varieties of sorghum in both regions. Statistically significant variables are: the agroecological zone, the age of the farmer, the training received on improved varieties, membership to farmers' organization, land area planted with sorghum, access to credit, availability of improved varieties. All these variables positively influence except farmer's age which negatively influence the adoption of improved varieties of sorghum.

Agro-ecological zone: the agro-ecological zone in center north positively and significantly influence the adoption of improved varieties of sorghum at $1 \%$. This means that being in an area with low rainfall leads producers to protect themselves from the effects of climate change by adopting more improved varieties. Marginal effects show that being in the agro-ecological zone of center north increases the probability of adoption of improved varieties for 0.59 points, all other things being equal. These results are consistent with the findings of Kaliba et al. (2000); Nouhoheflin et al. (2003); Adekambi et al. (2010); Kansiimei et al. (2014).

It also appears that the region of Boucle du Mouhoun, the second study area, benefited from favorable natural resources in the large majority of its territory such as its climate (rainfall and temperature), the presence of the river Mouhoun and rich enough soils for agricultural production. These favorable natural factors in terms of physical geography have contributed to make this region the food store in Burkina Faso in terms of cereals production (sorghum, pearl millet, maize). The importance of cereal crops in the study area prevailed in selecting it to conduct research on improved varieties of sorghum and pearl millet for several years. In fact, the second study area is not out of uncertainty in terms of irregularity in agricultural production caused by climate change. The geographic area comprising the two study zones, the region of Boucle du Mouhoun, mainly the provinces of Mouhoun, Kossi and Banwa et the province of Sanmatenga in the region of center north, represents in fact two agro-ecological zones differentiated by their rainfall and their production system, whereby their selection and implication in projects of participative selection and/or production and diffusion of improved varieties of sorghum for several years (Trouche G. et al., 2016).

Membership of farmers' organization: this variable positively and significantly influences the adoption of improved varieties of sorghum at $10 \%$. This implies that a producer, member of farmer organization is apt to adopt improved varieties of sorghum than the one who does not belong to an organization. Marginal effects show that the fact of being member of a farmer organization increases the probability of adoption of improved varieties of 
sorghum for 0.16 points, all other things being equal. These results are in agreement with those found by other authors (Abdoulaye et al., 2014; Ndjadi. et al., 2017).

Two farmers' organizations UGCPA and AMSK are involved in a relatively long space-time innovation started in the 2002's in participative breeding, production and diffusion projects of improved seeds of sorghum (Trouche G. et al., 2016). From this long experience of partnership, these two organizations, mainly producers who are affiliated to them have benefited from trainings in different fields on improved varieties of sorghum and pearl millet in many locations in the regions of Boucle du Mouhoun and center north.

Training received on improved varieties of sorghum: This variable positively and highly significantly (1\%) influences the adoption of improved varieties of sorghum. This means that having received training on improved varieties positively influences the adoption of improved varieties. Marginal effects, on the other hand, show that being trained on improved varieties increases the probability of adoption of improved varieties of sorghum for 0.26 point, all things being equal. These results are consistent with those of Abdoulaye, et al. (2014); Ademe et al. (2017); Musika, (2017); Salih et al. (2018); CORAF, (2018). Trouche G. et al. (2016) reported that trainings permitted to reinforce interaction capacities between farmers and breeders which enhanced the development of participatory research methods. The trainings have contributed over the years to strengthen the skills of producers in various fields.

Availability of improved sorghum varieties: it is a variable that positively and highly significantly (1\%) influences the adoption of improved varieties of sorghum. This means that making improved varieties available to the producers positively influence on the adoption of improved sorghum varieties. Marginal effects show that making improved varieties available increases the probability of adopting improved sorghum varieties for 0.30 points, all other things being equal. These results are consistent with those found by Ofuoku et al. (2011); Miah et al. (2015); Salih et al. (2018).

Capacity building of producers, specialization of some of them in improved seed production, training in commercialization and marketing, construction of seed storage facilities, dissemination of seeds and improvement of the local seed system were some factors among others that contributed to make improved sorghum varieties available in the studied areas. Packaging seeds in mini-bags of $100 \mathrm{~g}$ to $1 \mathrm{~kg}$, available in seed shops tested by the project HOPE, renders improved sorghum seeds accessible to small producers (men, women and young).

Age of producer: the age of the producer significantly and negatively influences the adoption of improved varieties of sorghum. This means that young producers adopt more improved sorghum varieties than old producers. Marginal effects show that being aged decrease the probability of adopting improved sorghum varieties for an average of 0.011 point, all other things being equal. These results are consistent with those of KinkingninhounMedagbe et al. (2013); Awotide et al. (2014), Amsalu Dachito et al. (2017); CHANDIO and JIANG (2018).

Land area planted with sorghum: it is a variable that positively and significantly influences the adoption of improved varieties of sorghum at $10 \%$ significance level. Meaning that possessing a large land area positively impact the adoption of improved sorghum varieties. Producers having allocated small land areas to sorghum less adopt improved varieties of sorghum while those having allocated large land areas to sorghum adopt them more. Marginal effects show that having allocated large land areas to sorghum increases the probability of adoption of improved sorghum varieties for 0.5 points, all other things being equal. These results are consistent with those of Mahoussi et al. (2017) et Ouedraogo and Dakouo (2017).

Access to credit: this variable positively and significantly (5\%) influences the adoption of improved varieties of sorghum. This implies that producers who have access to credit are more willing to adopt improved varieties of sorghum. Marginal effects show that having access to credit increases the probability of adoption of improved varieties of sorghum for 0.2 point, all other things being equal. These results corroborate those of Awotide et al. (2014); Okeke-Agulu and Onogwu, (2014); Gebresilassie and Bekele (2015); Amsalu et al. (2017). 
Table 3: Results of the econometric modeling (Probit)

\begin{tabular}{|c|c|c|c|c|}
\hline Variables & Coefficients & Standard Error. & P-value & Marginal effect \\
\hline Zone & 2.480284 & 0.4347056 & $0.000 * * *$ & 0.5905237 \\
\hline Age & -0.0383592 & 0.0133392 & $0.004 * * *$ & -0.0111349 \\
\hline Sex & 0.0870653 & 0.3411668 & 0.799 & 0.0257582 \\
\hline Education level & 0.1835119 & 0.3251987 & 0.573 & 0.0511442 \\
\hline Training on improved varieties & 1.21719 & 0.4125165 & $0.003 * * *$ & 0.2658502 \\
\hline Membership of farmers organization & 0.5385376 & 0.2971732 & $0.070 *$ & 0.1611107 \\
\hline sorghum land area & 0.1739496 & 0.0995399 & $0.081^{*}$ & 0.0504939 \\
\hline Access to credit & 0.8773223 & 0.3777086 & $0.020 * *$ & 0.2013948 \\
\hline Availability of varieties & 0.9256368 & 0.2906196 & $0.001 * * *$ & 0.3030536 \\
\hline cons & -0.5850796 & 0.5668365 & 0.302 & \\
\hline \multicolumn{5}{|c|}{$\begin{array}{l}\text { of obs. }= \\
\text { i2 }(8)=47 \\
\text { chi2 }=0.0 \\
\text { R2 }=0.3865\end{array}$} \\
\hline
\end{tabular}

\section{Conclusion and policy implication}

The objective of the present study was to determine and analyze the socio-economic factors that influence the adoption of improved varieties of sorghum in the regions of center north and Boucle du Mouhoun in Burkina Faso. To achieve these results, statistical and econometric methods were used to identify and analyze the factors influencing the adoption of improved varieties of sorghum. Results of the study showed that seven variables influence the adoption of improved varieties of sorghum in these regions. These variables are: agro-ecological zone, age of producer, training received on improved varieties, membership of farmers' organization, land area planted with sorghum, access to credit and finally the availability of improved varieties. All these variables positively influence the adoption of improved varieties of sorghum except the age of the producer that negatively influences it. These results suggest that training in favor of producers should be intensified and their access to credits should be facilitated as well. Improved varieties seeds should be made available to them. A combination of these actions will undoubtedly increase agricultural productivity and thus help to achieve food security.

Acknowledgments: at the end of this study, the authors would like to express their sincere gratitude to ICRISAT through the project HOPE II for financing the survey. The project HOPE (Harnessing Opportunities for Productivity Enhancement), supported by the Bill and Melinda Gates implemented by ICRISAT in collaboration with national partners' form ten countries.

\section{References}

Abdoulaye T., Abass A., Maziya-Dixon B., Tarawali G., Okechukwu R ., Rusike J., Alene A., Manyong V. and Ayedun B.(2014). Awareness and adoption of improved cassava varieties and processing technologies in Nigeria, Journal of Development and Agricultural Economics.Vol. 6(2), pp. 67-75, February, 2014 , DOI: 10.5897/JDAE2013.006 ISSN 2006-9774 C 2014 Academic Journals http://www.academicjournals.org/JDEA

Adekambi, Souléïmane Adéyèmi; ADEGBOLA, Patrice Ygué; GLELE Eugène K. A.; AGLI, Charles K. et TAMEGNON, Bertin A(2010). Contribution des innovations technologiques agricoles à l'amélioration de la productivité : cas des variétés améliorées de manioc au Bénin : Contributed Paper presented at the Joint 3rd African Association of Agricultural Economists (AAAE) and 48th Agricultural Economists Association of South Africa(AEASA) Conference, Cape Town, South Africa, September 19-23, 2010.

Ademe, Y., Shafi, T., Kebede, T., \& Mullatu, A. (2017). Evaluation of the environmental and economic effectiveness of soil and water conservation practices in Wenago District, Southern Ethiopia. Journal of Development and Agricultural Economics, 9(3), 37-45.

Amsalu Dachito, Habtamu Lema, Abiy Muluken, Gutema Arole, Mureta Abrahim , Elsabeth Alemu(2017). Determinant of Improved Modern Agricultural Inputs adoption in Case of Woliso Woreda. Journal of Economics and Sustainable Development www.iiste.org. ISSN 2222-1700 (Paper) ISSN 2222-2855 (Online) Vol.8, No.19, 2017

Awotide BA, Abdoulaye T, Alene A, Manyong VM (2014). Assessing the extent and determinant of adoption of improved cassava varieties in south-western Nigeria. J Dev Agric Econ 6(9):376-385

Barry Silamana (2016). Déterminants socioéconomiques et institutionnels de l'adoption des variétés améliorées de maïs dans le Centre-Sud du Burkina. Revue d'Economie Théorique et Appliquée ISSN : 1840-7277 Volume 6 - Numéro 2 - Décembre 2016 pp 221-238 
Barro/Kondombo Clarisse Pulcherie (2010).Diversités agro-morphologique et génétique de variétés locales de sorgho (Sorghum bicolor [L.]Moench) du Burkina Faso. Eléments pour la valorisation des ressources génétiques locales. Thèse de doctorat en Sciences Biologiques Appliquées. Universite de Ouagadougou, 2010. Burkina Faso.

Barro-Kondombo C.P., vom Brocke K., Chantereau J., Sagnard F., et Zongo J. D., (2008). Caractérisation de l'agrobiodiversité de l'agrosystème aux gènes : Variabilité phénotypique des sorghos locaux de deux régions du Burkina Faso : la Boucle du Mouhoun et le Centre-Ouest. Cahiers Agricultures vol. 17, 107- 113.

Bourbonnais Régis (2015). Econométrie : Cours et exercices corrigés. Dunod. 9 ème édition . 25 pages.

Chango Abbas Ali, Jiang Yuansheng (2018).Determinants of Adoption of Improved Rice Varieties in Northern Sindh, Pakistan. Rice Science, 2018, 25(2): 103-110; Science Direct. Available online at www.sciencedirect.com

Conseil Ouest et Centre Africain pour la Recherche et le Développement Agricoles (CORAF/WECARD) (2018). Centre National de Spécialisation sur le maïs (CNS-Maïs). Impact de l'adoption des variétés améliorées de maïs sur le bien-être des maïsiculteurs au Benin, au Burkina-Faso, en Côte d'ivoire et au Mali. Rapport régional. 59 pages, Février 2018

DGPER.(2012).Structure générale de l'agriculture, RGA 2008, Ministère de l'Agriculture et de l'Hydraulique (MAH). Ouagadougou ; Burkina Faso, 116p.

DGPER (2011). Stratégie Nationale de Développement des Filières Agricoles au Burkina Faso. Rapport final. Septembre 2011.

Gebresilassie Leake and Bekele Adam (2015). Factors determining allocation of land for improved wheat variety by smallholder farmers of northern Ethiopia. Journal of Development and Agricultural Economics. Vol. 7(3), pp. 105-112, March, 2015 DOI: 10.5897/JDAE2014.0621, Article Number: 4BCB9CC50612 ISSN 20069774

Kaliba, Aloyce R.M., Verkuij, H., Mwangi. (2000). Factors Affecting Adoption of Improved Maize Seeds and Use of Inorganic Fertilizer for Maize Production in the Intermediate and Lowland Zones of Tanzania, Journal of Agricultural and Applied Economics, Cambridge University Press, vol. 32(01), pages 35-47, April.

Kansiime Monica K., Wambugu Stephen K., shisanya Chris A.(2014). Determinants of Farmers' Decisions to Adopt Adaptation Technologies in Eastern Uganda. Journal of Economics and Sustainable Development www.iiste.org; ISSN 2222-1700 (Paper) ISSN 2222-2855 (Online). Vol.5, No.3, 2014

Kinkingninhoun-Medagbe, F.M., Diagne, A, Bonou, A., Seck, P. A. and Amovin-Assagba, E.(2013). Problématique semencière dans la riziculture africaine : accès et demande des semences améliorées par les producteurs et perspectives pour améliorer le système. A Paper prepared for the 4th International Conference of the African Association of Agricultural Economists

Mahoussi, F. E. Adegbola P. Y, Zannou . A. Hounnou E. F. Biaou, G.(2017).Adoption assessment of improved maize seed by farmers in Benin Republic: Journal of Agricultural and Crop Research Vol. 5(3), pp. 32-41, September 2017

MAHRA (2010). Diagnostic du secteur semencier du Burkina Faso, document final, Ouagadougou, $81 \mathrm{p}$.

Miah, M., Afroz, S., Rashid, M. and Shiblee, A.(2015). Factors affecting of improved sesame technologies in some selected areas in Bangladesh: An empirical study, scientific journal of Krishi foundation, The Agriculturalists 13(1):140-151(2015), ISSN 2304 - 7321 (online

Musika Lauren (2017).Determinants of adoption of improved soybean varieties among smallholder farmers in eastern Uganda. B.sc. agriculture (MAK) , Reg. no 2013/hd02/1917u. Master of science in agricultural economics of makerere university. December, 2017

Ndjadi Serge Shakanye, Nna'ka Arsène Rudahaba, Mudosa Chance Bahati, Basimine Géant Chuma et Basengere Espoir Bisimwa(2017). Analyse des déterminants de l'adoption des variétés du manioc dans le Sud - Kivu, République Démocratique du Congo. Afrique SCIENCE 13(3) (2017) 113 - 124. ISSN 1813-548X, http://www.afriquescience.info

Nouhoheflin, T. Coulibaly O. et Adégbidi A.(2003).Impact de l'adoption des nouvelles technologies sur l'efficacité de la production du niébé au Bénin. Bulletin de la Recherche Agronomique du Bénin No $40-$ Juin 2003

Ntsama Etoundi, S.M., Kamgnia Dia, B. (2008). Determinants of the adoption of improved varieties of Maize in Cameroon: case of CMS 8704" Proceedings of the African Economic Conference

Ofuoku AU, Egho E and Enujeke E (2011): Propensity of cowpea (vigna unguiculata) farmers to adopt neem in controlling pest in delta state, nigeria. Tropical Agricultural Research \& Extension 14(3): 2011

Okeke-Agulu, K.I and Onogwu, G.O (2014). Determinants of farmers'adoption decisions for improved pearl millet variety in Sahel Savanna zone of northern Nigeria. Journal of Development and Agricultural Economics. Vol.6(10).pp.437-442, october, 2014. DOI :10.5897/JDAE2013.0532

Ouédraogo M. , Dakuo D.(2017). Evaluation de l'adoption des variétés de riz NERICA dans l'Ouest du Burkina Faso. African Journal of Agricultural and Resource Economics Volume 12 Number 1 pages 1-16, 2017 
Rogers E. (1995). Diffusion of innovation, Free Press, New York, 4th edition.

Salih Elagab Elsheikh, Abdallaziz A Hashim, Hamid H Faki, Eltighani M Elamin (2018). Factors Affecting Adoption of Improved Varieties of Sorghum, Millet, Groundnut and Sesame in North Kordofan State. Agri Res \& Tech: Open Access J. 2018; 13(4): 555889. DOI: 10.19080/ ARTOAJ.2018.13.555889

Trouche Gilles, Vom Brocke Kirsten, Temple Ludovic, Guillet Marion (2016) : La sélection participative du sorgho au Burkina Faso, CIRAD- UMR AGAP et Innovation, 205 pages

World Bank (2016).World Development Indicators Retrieved from https://data.worldbank.org/products/wdi 